\title{
Characteristics of Bacillus thuringiensis isolates indigenous soil of South Sumatra (Indonesia) and their pathogenicity against oil palm pests Oryctes rhinoceros (Coleoptera: Scarabaeidae)
}

\author{
YULIA PUJIASTUTI ${ }^{1, \boldsymbol{v}}$, ARSI ARSI ${ }^{1}$, SOFIA SANDI ${ }^{2}$ \\ ${ }^{1}$ Department of Plant Protection, Faculty of Agriculture, Universitas Sriwijaya. Jl. Raya Palembang-Prabumulih Km 32, Indralaya, Ogan Ilir 30662, \\ South Sumatra, Indonesia. Tel.: +62-711-580663, Fax.: +62-711-580276, vemail: ypujiastuti@unsri.ac.id \\ ${ }^{2}$ Department of Animal Husbandry, Faculty of Agriculture, Universitas Sriwijaya. Jl. Raya Palembang-Prabumulih Km 32, Indralaya, Ogan Ilir 30662, \\ South Sumatra, Indonesia
}

Manuscript received: 8 December 2019. Revision accepted: 3 March 2020.

\begin{abstract}
Pujiastuti Y, Arsi, Sandi S. 2020. Characteristics of Bacillus thuringiensis isolates indigenous soil of South Sumatra (Indonesia) and their pathogenicity against oil palm pests Oryctes rhinoceros (Coleoptera: Scarabaeidae). Biodiversitas 21: 12871294. Bacillus thuringiensis is a gram-positive, entomopathogenic bacterium that could be isolated from soil and be used to control various plant pests. Oryctes rhinoceros is an important pest in oil palm. Application of B. thuringiensis-based bioinsecticides is an alternative in controlling these pests. The purposes of this study were to isolate and identify B. thuringiensis bacteria from the soil of South Sumatra, production of $B$. thuringiensis-based bioinsecticides and to test their toxicity to $O$. rhinoceros larvae. The study was conducted in several cities/districts in the province of South Sumatra. Soil samples were taken from various habitats and B. thuringiensis isolates were grown on NGKG agar media. Among 76 soil samples (6 districts and 2 cities) B. thuringiensis colonies were obtained leading to 24 isolates of $B$. thuringiensis. Toxicity screening tests for armyworm Spodoptera litura were 55.79\% (53 isolates) and their mortality to $25.26 \%$ O. rhinoceros larvae (24 isolates). From these isolates whose effectively killed $O$. rhinoceros larvae, 10 isolates were taken and propagated with Nutrient Broth (NB) and biourine enriched with 5\% molasses. Number of spores produced was counted during 24, 48 and 72 hours. Furthermore, a bioassay test was carried out on $O$. rhinoceros larvae for 7 days. Isolate of KJ3P1 caused the highest mortality of $O$. rhinoceros larvae after 7 days of observation. SDS Page resulted in KJ3P1 and KJ3R5 isolates showing several bands whose content of various types of protein molecular weight. Isolation of B. thuringiensis in South Sumatra produced 2 isolates potentially to be active ingredients in production of bioinsecticides which were effective in killing $O$. rhinoceros larvae.
\end{abstract}

Keywords: Bacillus thuringiensis, biological control, Oryctes rhinoceros, toxicity

\section{INTRODUCTION}

Oryctes rhinoceros (Coleoptera: Scarabaeidae) is an important oil palm plant pest both in immature and mature stage of plants (Susanto et al. 2011). The application of zero waste by re-entering empty bunches in oil palm plantations increases $O$. rhinoceros larvae population. Oil palm empty fruit bunches which decompose into organic matter become suitable breeding sites for these larvae (Santi and Sumaryo 2008). The decline in palm oil yields can occur after the attack. Heavy injury to palm oil leaves $(\geq 90 \%$ ) can reduce production by more than $70 \%$ in the first year and continue for the subsequent years (Sudharto and Guritno 2003). Control of O. rhinoceros by using entomopathogens is an alternative when the use of synthetic chemical insecticides is not able to solve pest problems. For example, Bacillus thuringiensis used to pest control has been tried to control Metisa plana caterpillars (Khaeruni and Purnamaningrum 2012; Ahmad et al. 2017; Kamarudin et al. 2017), but to controlling O. rhinoceros is still not much studied.

Bacillus thuringiensis works like stomach poison. Proteins and spores of $B$. thuringiensis produced during sporulation must be ingested and digested in the midgut of insects (Mizuki et al. 1999; Bravo et al. 2015a). The specificity of host is a unique feature of B. thuringiensis. In its grouping, B. thuringiensis is divided into groups based on their insecticidal protein content (Jouzani et al. 2017). The discovery of new isolates is a big chance in producing isolates who is toxic to insect pests (Bravo et al. 2015b). After obtaining B. thuringiensis isolates, their application for controlling insect pest becomes important. Bioinsecticides need to be made with materials that are easily obtained, inexpensive and abundant. Therefore, waste materials such as bio-urine and molasses can be used as media in the propagation of $B$. thuringiensis (Purnawati et al. 2014; Salazar-Magallon et al. 2015; Pujiastuti et al. 2018). The specificity of the insect pest host of $B$. thuringiensis can also be explained by its protein content. Wiest et al. (2015) and Osman et al. (2015) explained specifically $B$. thuringiensis which active against Lepidoptera content a protein molecular weight of 130 $\mathrm{kDa}$, while those active against Coleoptera own a molecular weight of 14-133 kDa (Fernandez and LópezPazos 2011). Therefore it is necessary to investigate $B$. thuringiensis isolates from soil isolated in South Sumatra province and their toxicity to Oryctes larvae by paying attention to their protein content. 


\section{MATERIALS AND METHODS}

\section{Materials}

Soil sampling was carried out in 6 districts and 2 cities in the province of South Sumatra, Indonesia as shown in Figure 1. Altitude varies from lowland $(8 \mathrm{~m})$ to highlands $(850 \mathrm{~m})$. The habitat for sampling also varies according to local conditions including lowland peat soils, tidal swamp soils and annual plantations (Table 3).

\section{Procedures}

Soil sampling

Soil samples were taken from various habitats. The surface of soil was cleaned from litter and then measured a distance of about $30 \mathrm{~cm}$ from the plant stem with a depth of $5 \mathrm{~cm}$. The soil was taken as much as $\pm 500 \mathrm{~g}$ in each place. The soil samples were then put into a plastic bag, tightly bound, labeled with location and date of collection, then taken to the laboratory and stored in the refrigerator until further analyses.

\section{Isolation method}

Isolation of $B$. thuringiensis was performed in accordance with the procedures of Rusmana and Hadinata (1994). One gram of soil samples was diluted well in 15 $\mathrm{mL} \mathrm{H}_{2} \mathrm{O}$ in test tube by shaking well until perfectly diluted. One $\mathrm{mL}$ of upper part of dilution was taken in eppendorf tube, added by $1 \mu \mathrm{L}$ Triton X-100, and heated in water bath $85^{\circ} \mathrm{C}$ for 15 minutes. With a sterile spatula, the solution was streaked on the $\mathrm{NaCl}$ Glycine $\mathrm{Kim}$ and Goepfert (NGKG) medium on Petri dish. Petri dish was incubated at $30^{\circ} \mathrm{C}$ for 24-72 hours. Colonies of B. thuringiensis grow in white color. After 24-72 hours incubation, proteinaceous parasporal inclusion bodies produced. Identification of $B$. thuringiensis was done by observing microscopic cells test and gram staining test.

\section{Screening test}

Bacillus thuringiensis isolates that have been identified were grown on Nutrient Broth media. Their toxicity was tested using armyworm $3^{\text {rd }}$ instar larvae of S.litura and $1^{\text {st }}$ instar of $O$. rhinoceros. Every isolate required 20 individuals of each species. Mortality was used as a reference for subsequent testing.

\section{Propagation of Bacillus thuringiensis}

Propagation of $B$. thuringiensis as bioinsecticide was carried out using cow bio-urine enriched with 5\% molasses. For production of bioinsecticides, preculture or seed culture was first made (Valicente et al. 2010). A total of $10 \mathrm{~mL}$ NB in $200 \mathrm{~mL}$-Erlenmeyer was given one predetermined isolate ose needle. The Erlenmeyer was then put in the fermenter for 12 hours $200 \mathrm{rpm}$ at room temperature. From the Erlenmeyer, it was taken $5 \mathrm{~mL}$ of seed culture and added with $10 \mathrm{~mL}$ of $\mathrm{NB}$ and once again fermented for 12 hours. Seed culture was ready to be used as a basis for making Bt-based bioinsecticides. A $100 \mathrm{~mL}$ of cow biourine enriched with $5 \%$ molasses were sterilized with autoclave for $20 \mathrm{~min}$ at $121{ }^{\circ} \mathrm{C}$ and $1 \mathrm{~atm}$ pressure. Under aseptic conditions, as much as $10 \mathrm{~mL}$ of seed culture was put into an Erlenmeyer containing $100 \mathrm{~mL}$ of cow biourine enriched with $5 \%$ molasses. It was fermented at room temperature at $200 \mathrm{rpm}$ for 72 hours. Numbers of bacterial/ spore cells were observed at 24,48 , and 72 hours. Ten isolates that showed the highest number of spores were chosen to test their toxicity against $O$. rhinoceros larvae.

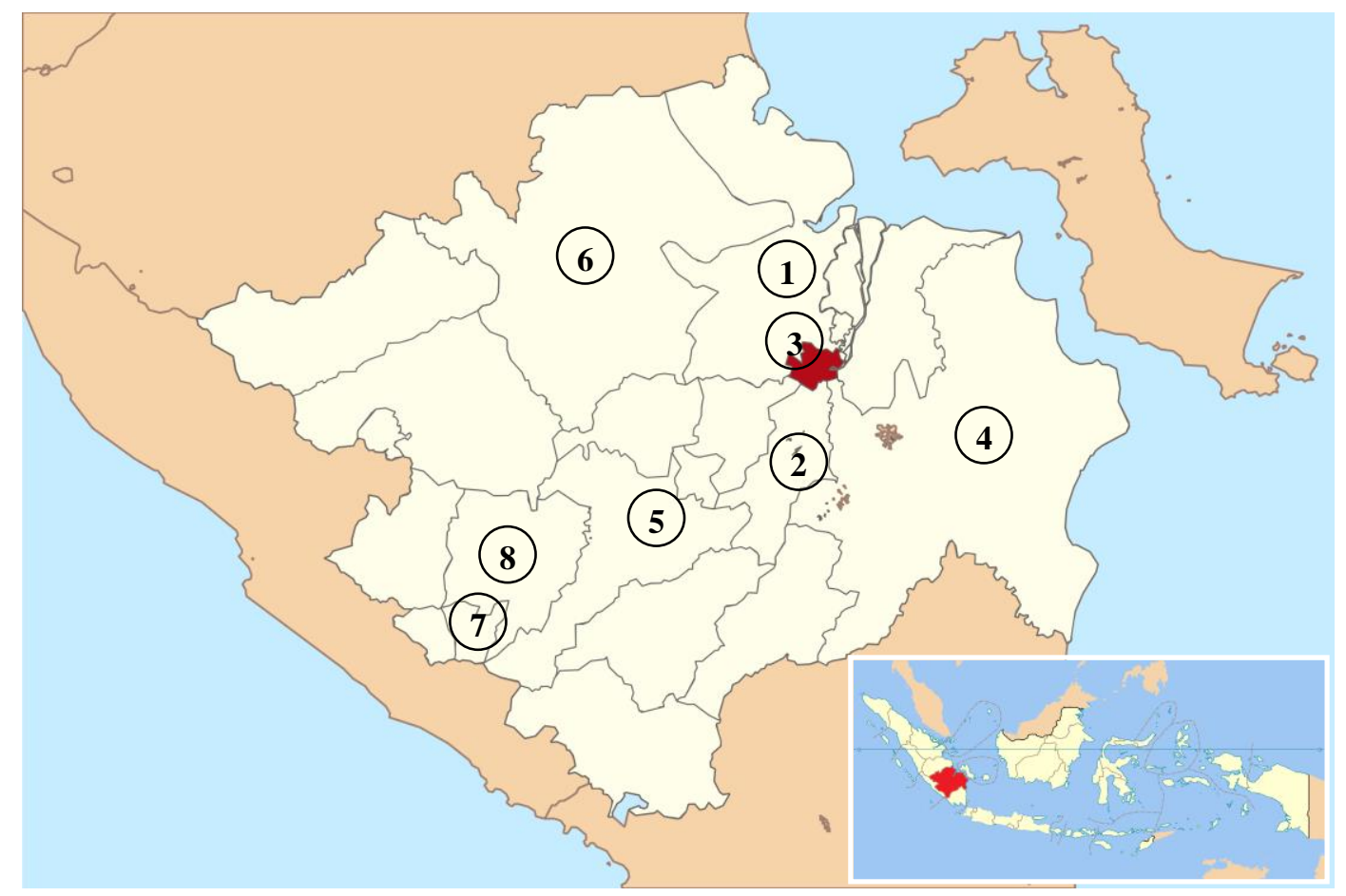

Figure 1. Location of soil sampling in 6 districts and 2 cities in South Sumatra Province, Indonesia, i.e. 1. Banyuasin, 2. Ogan Ilir, 3. Palembang, 4. Ogan Komering Ilir, 5. Muara Enim, 6. Musi Banyuasin, 7. Pagar Alam, 8. Lahat 
Tabel 1. Bacillus thuringiensis isolates original from soil in some cities and districts of South Sumatra, Indonesia

\begin{tabular}{clcccc}
\hline No. & Cities/dustricts (m asl) & $\begin{array}{c}\text { No. of soil } \\
\text { samples }\end{array}$ & No.of colony (BC) & $\begin{array}{c}\text { No. of B. } \\
\text { thuringiensis } \\
\text { colonies (Bt) }\end{array}$ & $\begin{array}{c}\text { \% isolat Bt }(\mathbf{B t} \text { index }= \\
(\mathbf{B t} / \mathbf{B C}) \mathbf{x 1 0 0 \%})\end{array}$ \\
\hline 1 & Banyuasin (63) & 10 & 56 & 19 & 33,9 \\
2 & Ogan Ilir (18) & 18 & 73 & 15 & 20,5 \\
3 & Palembang (8) & 13 & 26 & 8 & 30,8 \\
4 & Ogan Komering Ilir (18) & 6 & 30 & 4 & 13,3 \\
5 & Muara Enim (45) & 8 & 57 & 15 & 26,3 \\
6 & Musi Banyuasin (15) & 10 & 36 & 10 & 27,8 \\
7 & Pagar Alam (780) & 6 & 25 & 6 & 72,0 \\
8 & Lahat (500) & 5 & 18 & 95 & 33,3 \\
\multicolumn{2}{l}{ Total/average of \% Bt isolates } & 76 & 321 & 29,6 \\
\hline
\end{tabular}

\section{Bioassay test}

Bioassay test was conducted by using $1^{\text {st }}$ instar larvae of $O$. rhinoceros. For each $B t$ isolate-based bioinsecticide treatment, there was be 5 replications, with 10 individuals/replication. A total of $50 \mathrm{~g}$ of decomposed-oil palm bunches were put into $10 \times 10 \times 5 \mathrm{~cm}$ plastic containers. The soil was sprayed singly with $5 \mathrm{~mL}$ of bioinsecticide and air-dried. Oryctes rhinoceros were then put into the container and allowed to eat. The mortality was observed every day until $7^{\text {th }}$ day.

\section{Isolation of Bacillus thuringiensis protein}

One colony of $B$. thuringiensis from slant agar was transferred using inoculation loope of into $1 \mathrm{~mL} \mathrm{NB}$ medium and shook at $25^{\circ} \mathrm{C}$ overnight. This culture was then transferred into $10 \mathrm{~mL}$ of $\mathrm{NB}$ medium and shook at $25^{\circ} \mathrm{C}$ for 2 days. The cells were harvested after centrifugation at $13 \mathrm{krpm}$ for $10 \mathrm{~min}$, washed in distilled water twice and collected white pellets. The pellet was suspended in distilled water. Precipitation was collected by centrifugation at $13 \mathrm{krpm}$ for $10 \mathrm{~min}$. It was re-suspended in water and added $3 \mathrm{ml}$ of $0.5 \mathrm{M} \mathrm{NaCL}$. For collecting precipitation it was centrifuged at $10 \mathrm{krpm}$ for $15 \mathrm{~min}$. This step ( $\mathrm{NaCl}$ wash) was done at least two times and continued with distilled water wash two times. The cells were re-suspended in $5 \mathrm{~mL}$ of $10 \mathrm{mM}$ Tris $\mathrm{HCl} \mathrm{pH} 8$ containing $10 \mathrm{mM}$ EDTA and disrupted by a sonicator. This solution was kept on ice for 30 min after addition of $100 \mu \mathrm{L}$ of mercapto-ethanol and adjustment of $\mathrm{pH} 10.5$. To collect supernatant contained protein, it was centrifuged down at $10 \mathrm{krpm}$ for $10 \mathrm{~min}$. The last step was adjusting to $\mathrm{pH} 4.4$ and kept the crystal protein on $4^{\circ} \mathrm{C}$ for long storage.

\section{Weighing molecular mass of crystal protein by SDS-PAGE analysis}

Crystal proteins isolated from B. thuringiensis strains were analyzed by sodium dodecyl polyacrylamide gel electrophoresis (SDS-PAGE). SDS-PAGE was carried out by the method of He (2011) using 10\% running and 4\% stacking gels. The crystal proteins were prepared as follows: $10 \mu \mathrm{l}$ of crystal protein kept at $\mathrm{pH} 4.4$ was centrifugated down at $10 \mathrm{k} \mathrm{rpm}$ for $1 \mathrm{~min}$ to collect precipitation. It was suspended in the equal volume of TE. After addition of SDS sample buffer (1: 4, v/v), protein sample was boiled for $3 \mathrm{~min}$. The centrifugation at $7 \mathrm{krpm}$ for 1 min was done to purify the protein solution and electrophoresed.

\section{Data analyses}

Data on spores density of $B$. thuringiensis and mortality of $O$. rhinoceros were analyzed using analysis of variance (ANOVA). Tukey's Honestly Significant Difference (HSD) Test was employed to test for significant differences among the treatments (isolates) at $\mathrm{P}=0.05$. All data were analyzed using software of SAS University Edition 2.7 9.4 M5.

\section{RESULTS AND DISCUSSION}

\section{Soil sampling}

Soil sampling was carried out in 6 districts and 2 cities in the province of South Sumatra. Soil samples were taken from a variety of habitats, especially in free polluted habitats by chemicals and generally annual plantation or secondary forests. Among the number of soil samples, the average B. thuringiensis isolates obtained was $29.6 \%$ (Table 1). Bacterial colonies grow after incubation on the first day were very small and grow almost flat with the media. On the second day, the shape of the bacteria was enlarged and rather wide however they did not collide with each other. On the third day enlargement of bacterial elevation was clearly seen on the solid media (Figure 2.A). Of cell observation under a microscope, it appeared in the form of bacilli and some obtained formed spores (Figure 2.B).

\section{Screening test}

Screening tests were carried out on third-instar Spodoptera litura larvae and first-instar Rhinoceros oryctes larvae. From the screening test results obtained that not all isolates of $B$. thuringiensis were found to be able to kill $S$. litura or $O$. rhinoceros. The screening test resulted in $55.79 \%$ of these isolates were able to kill S. litura larva while $25.06 \%$ of $B$. thuringiensis isolates were active against $O$. rhinoceros larvae (Table 2). 


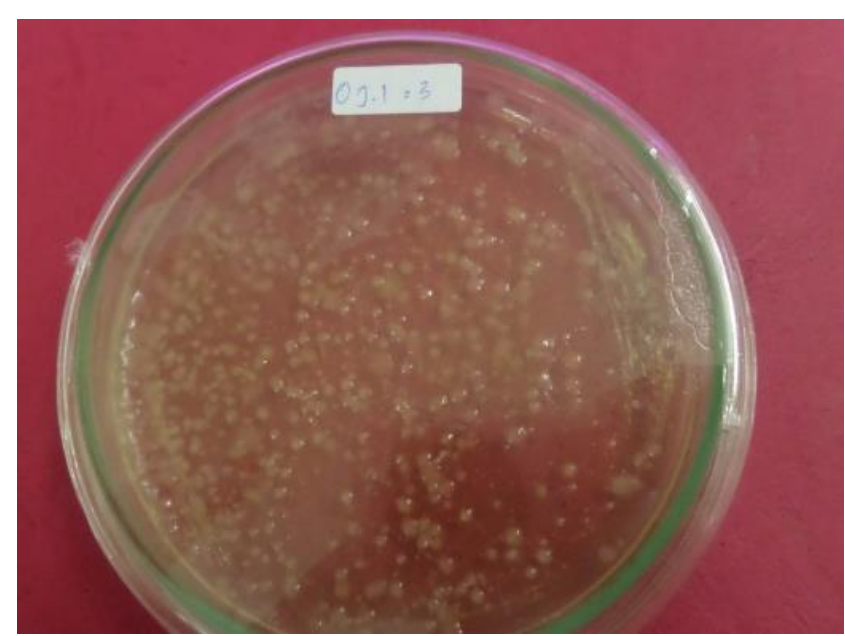

A

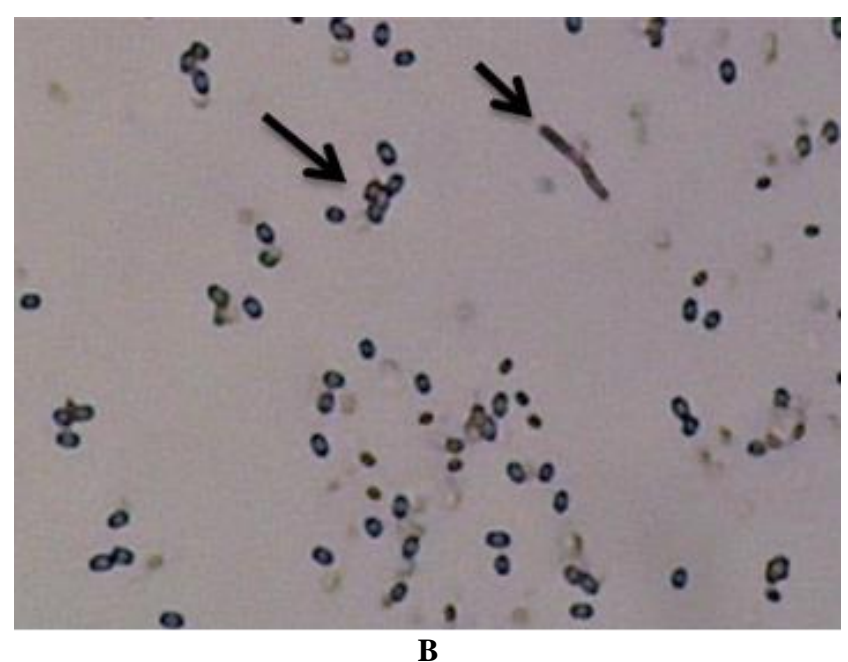

B

Figure 2. Colonies of B. thuringiensis (A) dan bacterial cel of B. thuringiensis (magnification $400 \mathrm{x}$ ) (B)

Among 24 isolates of $B$. thuringiensis which actively killed $O$. rhinoceros larvae, 10 isolates were chosen (Table $3)$. They were grown on NGKG media and propagated with NB media to determine spore density (Figure 2). In NGKG agar medium, B. thuringiensis isolates grew well to form colonies. In NB media, it was proved that 72 hours after propagation, the number of cells/spores increased. Each isolate grown on $\mathrm{NB}$ media was also propagated on Biourine media enriched with $5 \%$ molasses. Furthermore, spore densities were calculated at 24,48 , and 72 hours (Table 3).

\section{Spore density of Bacillus thuringiensis isolates}

Ten of $B$. thuringiensis isolates active to $O$. rhinoceros larvae grown on $\mathrm{NB}$ and Biourine enriched with 5\% molasses produced a fairly high spore density and varied from each isolate. Statistically, the amount of spore density was significantly different at each time of observation. Spore growth was gradually increased starting from 24 hours in number until 72 hours of observation. In propagation with NB media after 72 hours of fermentation, the highest spore density in $B t$-isolates was obtained on KJ3R5 code $\left(9.27 \times 10^{12}\right.$ spores $\left.\mathrm{mL}^{-1}\right)$, whereas in biourine media enriched with $5 \%$ molasses the highest density was in $\mathrm{KJ} 3 \mathrm{P} 1\left(0.71 \times 10^{12}\right.$ spores- $\left.\mathrm{ml}^{-1}\right)$. Spores densities of $B$. thuringiensis were showed in Table 4.

\section{Mortality of insect test}

In the bioassay test, death occurred starting on the third day after application, ranging between $1.3-8 \%$. On the fifth day, the deaths increased to $4-40 \%$. Some isolates began to show effectiveness in causing death on the fifth day. From the statistical tests, there were significant differences between isolates from controls (without treatment). The process of death symptoms may begin around 24 hours after application, however insect mortality started on the third day ranging from $1.3-8.0 \% 4.0-40 \%$ and $6.67-$ $81.33 \%$ on the third day, fifth day and seventh day, respectively. On the seventh day, there were 6 isolates showed a mortality rate above $50 \%$. Mortality data of $O$. rhinoceros larvae were presented in Table 4.

\section{Molecular weight of Bacillus thuringiensis protein}

Of the results of calculating molecular weights of protein using SDS-Page, several bands had been produced in various isolates. In isolate 1 (SMR) it was estimated to have a molecular weight of about $90 \mathrm{kDa}$ and $45 \mathrm{kDa}$, while in isolate 2 (MSP) was around $90 \mathrm{kDa}$. , Isolate 3 (KJ3R5) was predicted to possess a molecular weight of $130 \mathrm{kDa}, 90 \mathrm{kDa}$, and $45 \mathrm{kDa}$, while isolate $4(\mathrm{KJ} 3 \mathrm{P} 1)$ was 50-60 kDa. Isolate 5 (SASU) was suspected a molecular weight of $<45 \mathrm{kDa}$ and isolate 6 (MSKS) was around 90 kDa (Figure 4).

\section{Mortality symptom of larva Oryctes}

Mortality of $O$. rhinoceros larvae was characterized by changes in color, body texture and body shape. Firstly, healthy Oryctes larvae were white, however, 3 days after application, the symptoms of $B$. thuringiensis infection were marked by discoloration. On the seventh day, larvae died with a black body-color (Figure 3).

Table 2. Screening tests for Bacillus thuringiensis isolates against Spodoptera litura and Oryctes rhinoceros

\begin{tabular}{llll}
\hline \multicolumn{1}{c}{ Cities/districts } & $\begin{array}{c}\text { Number of } \boldsymbol{B} \text {. } \\
\text { thuringiensis } \\
\text { isolates }\end{array}$ & $\begin{array}{c}\text { Active } \\
\text { against } \boldsymbol{S} \text {. } \\
\text { litura }(\boldsymbol{\%})\end{array}$ & $\begin{array}{c}\text { Active against } \\
\text { o. rhinoceros } \\
(\%)\end{array}$ \\
\hline Banyuasin & 19 & $10(52.63)$ & $5(26.32)$ \\
Ogan Ilir & 15 & $8(53.33)$ & $2(13.33)$ \\
Palembang & 8 & $6(75.00)$ & $3(37.50)$ \\
Ogan Komering Ilir & 4 & $4(100)$ & $0(0.00)$ \\
Muara Enim & 15 & $9(60)$ & $5(33.33)$ \\
Musi Banyuasin & 10 & $5(50)$ & $4(40.00)$ \\
Pagar Alam & 18 & $7(38.89)$ & $3(16.67)$ \\
Lahat & 6 & $4(66.67)$ & $2(33.33)$ \\
Total & 95 & $53(55.79)$ & $24(25.26)$ \\
\hline
\end{tabular}

Notes: Larvae of Spodoptera $(\mathrm{n}=20$ individuals); Larvae of Oryctes $(\mathrm{n}=20$ individuals $)$ 

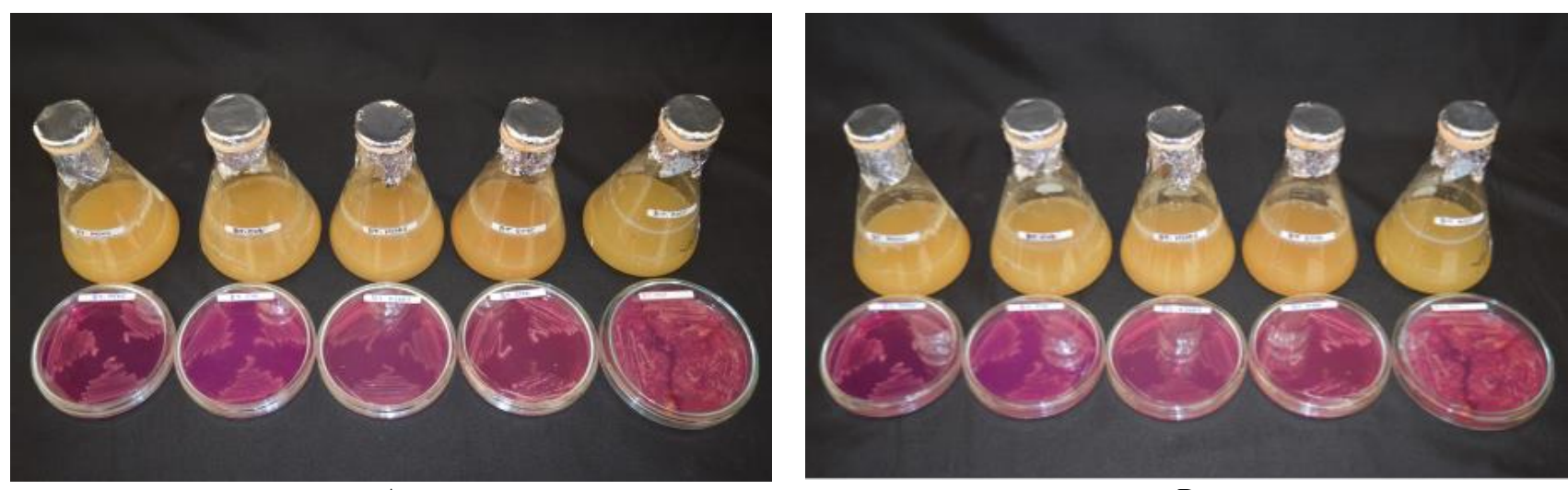

A

B

Figure 3. B. thuringiensis isolates and their propagation on NB media. Isolate codes: MSKS, CI4, KJ3R5, SMR, MSP. Isolate codes: KJ3P1, KJ3R3, LK, SASU, TPP

Table 3. The origin of isolated soil habitats

\begin{tabular}{lcccll}
\hline \multicolumn{1}{c}{ Cities/districts } & $\begin{array}{c}\text { Elevation } \\
(\mathbf{m} \text { asl })\end{array}$ & $\begin{array}{c}\text { B. thuringiensis active } \\
\text { to } \boldsymbol{O} \text {. rhinoceros }\end{array}$ & $\begin{array}{c}\text { Number of } \boldsymbol{B} \text {. } \\
\text { thuringiensis chosen }\end{array}$ & Habitat & Isolates codes \\
\hline Banyuasin & 63 & 5 & 1 & Peat soil & TPP \\
Ogan Ilir & 18 & 3 & 1 & Jackfruits tree & CI4 \\
Palembang & 8 & 2 & 1 & Sawo tree & SASU \\
Muara Enim & 45 & 5 & 2 & Mangoes tree & MSP, MSKS \\
Musi Banyuasin & 15 & 4 & 3 & Rambutan tree & KJ3P1, KJ3R5, KJ3R3 \\
Pagar Alam & 780 & 3 & 1 & Coffee tree & SMR \\
Lahat & 500 & 2 & 1 & Pepper tree & LK \\
Total & & 24 & 10 & & \\
\hline
\end{tabular}

Table 4. Spores density of Bacillus thuringiensis active against Oryctes rhinoceros larvae and propagated on NB media and biourine enriched with $5 \%$ molasses

\begin{tabular}{|c|c|c|c|c|c|c|}
\hline \multirow{3}{*}{ Isolates codes } & \multicolumn{6}{|c|}{ Spores density ( $\times 10^{12}$ spores-mL $L^{-1}$ ) } \\
\hline & \multicolumn{2}{|c|}{$24 \mathrm{~h}$} & \multicolumn{2}{|c|}{$48 \mathrm{~h}$} & \multicolumn{2}{|c|}{$72 \mathrm{~h}$} \\
\hline & $\begin{array}{c}\text { Biourine }+5 \% \\
\text { Molase }\end{array}$ & NB & $\begin{array}{c}\text { Biourine }+5 \% \\
\text { Molase }\end{array}$ & NB & $\begin{array}{c}\text { Biourine }+5 \% \\
\text { Molase }\end{array}$ & NB \\
\hline SMR & $3.25 \pm 0.13 \mathrm{ab}$ & $3.73 \pm 0.20 \mathrm{a}$ & $5.8 \pm 0.52 b$ & $5.42 \pm 0.20 \mathrm{ab}$ & $8.07 \pm 0.52 \mathrm{ab}$ & $7.82 \pm 0.24 \mathrm{abc}$ \\
\hline KJ3P1 & $6.73 \pm 0.47 c$ & $5.99 \pm 0.36 b$ & $8.31 \pm 0.28 b$ & $8.33 \pm 0.26 \mathrm{~d}$ & $9.71 \pm 0.28 b$ & $8.59 \pm 0.24 c$ \\
\hline KJ3R5 & $5.26 \pm 0.55 \mathrm{bc}$ & $4.55 \pm 0.29 \mathrm{ab}$ & $6.13 \pm 0.43 b$ & $6.74 \pm 0.24 \mathrm{bcd}$ & $8.19 \pm 0.43 a b$ & $9.27 \pm 0.29 \mathrm{c}$ \\
\hline MSP & $4.21 \pm 0.30 \mathrm{bc}$ & $4.47 \pm 0.35 \mathrm{ab}$ & $6.14 \pm 0.26 b$ & $7.93 \pm 0.12 \mathrm{~cd}$ & $8.11 \pm 0.26 a b$ & $9.21 \pm 0.14 \mathrm{c}$ \\
\hline SASU & $2.65 \pm 0.37 \mathrm{a}$ & $3.85 \pm 0.17 \mathrm{a}$ & $4.04 \pm 0.61 \mathrm{a}$ & $6.43 \pm 0.28 \mathrm{abcd}$ & $8.09 \pm 0.61 \mathrm{ab}$ & $8.07 \pm 0.29$ \\
\hline MSKS & $5.70 \pm 0.60 b c$ & $4.78 \pm 0.06 \mathrm{ab}$ & $6.91 \pm 0.47 \mathrm{a}$ & $6.23 \pm 0.47 \mathrm{abcd}$ & $7.98 \pm 0.47 a b$ & $7.70 \pm 0.40 \mathrm{bc}$ \\
\hline KJ3R3 & $5.11 \pm 0.63 \mathrm{bc}$ & $5.14 \pm 0.23 \mathrm{ab}$ & $6.37 \pm 0.60 \mathrm{a}$ & $6.78 \pm 0.36 \mathrm{bcd}$ & $7.40 \pm 0.60 \mathrm{ab}$ & $7.39 \pm 0.22 \mathrm{abc}$ \\
\hline LK & $6.39 \pm 0.40 \mathrm{c}$ & $4.73 \pm 0.09 \mathrm{ab}$ & $7.23 \pm 0.26 \mathrm{a}$ & $5.97 \pm 0.20 \mathrm{abc}$ & $7.36 \pm 0.26 a b$ & $7.46 \pm 0.39 \mathrm{abc}$ \\
\hline TPP & $5.51 \pm 0.51 b c$ & $4.18 \pm 0.29 a b$ & $6.77 \pm 0.50 \mathrm{a}$ & $5.09 \pm 0.40 \mathrm{ab}$ & $7.72 \pm 0.50 \mathrm{ab}$ & $6.38 \pm 0.46 \mathrm{ab}$ \\
\hline CI4 & $4.32 \pm 0.44 \mathrm{bc}$ & $3.87 \pm 0.50 \mathrm{a}$ & $5.5 \pm 0.47 \mathrm{a}$ & $4.78 \pm 0.27 \mathrm{a}$ & $6.95 \pm 0.47 \mathrm{a}$ & $6.26 \pm 0.33 \mathrm{a}$ \\
\hline F value & 6.49 & 3.47 & 4.12 & 8.92 & 2.51 & 6.54 \\
\hline F Table & 2.39 & 2.39 & 2.39 & 2.39 & 2.39 & 2.39 \\
\hline P-Value & 0.00 & 0.01 & 0.00 & 0.00 & 0.04 & 0.00 \\
\hline Tukeys HSD tests & 0.25 & 0.17 & 0.21 & 0.13 & 0.12 & 0.11 \\
\hline
\end{tabular}

Note: significantly different; values within a column (the data of each isolate) followed by the same letters were not significantly different at $\mathrm{P}<0.05$ according to Tukey's HSD test. Original data were transformed using Log transformation prior to statistical analysis 
Table 5. Bioassay tests on Oryctes larvae during 7 days of observation

\begin{tabular}{|c|c|c|c|}
\hline \multirow{2}{*}{ Isolates codes } & \multicolumn{3}{|c|}{ Average of mortality days of ..... (n=75 ind.) } \\
\hline & 3 & 5 & 7 \\
\hline SMR & $8.00 \pm 2.31 \mathrm{~b}$ & $28.00 \pm 4.00 \mathrm{~d}$ & $58.67 \pm 4.35 b$ \\
\hline KJ3P1 & $6.67 \pm 1.33 \mathrm{~b}$ & $25.33 \pm 4.81 \mathrm{~cd}$ & $81.33 \pm 7.62 b$ \\
\hline KJ3R5 & $8.00 \pm 2.31 \mathrm{~b}$ & $30.67 \pm 3.53 \mathrm{~d}$ & $86.00 \pm 1.88 \mathrm{~b}$ \\
\hline MSP & $6.67 \pm 1.33 b$ & $40.00 \pm 2.31 \mathrm{~d}$ & $66.67 \pm 2.88 \mathrm{~b}$ \\
\hline SASU & $8.00 \pm 2.31 \mathrm{~b}$ & $33.33 \pm 4.81 \mathrm{~d}$ & $58.67 \pm 2.18 \mathrm{~b}$ \\
\hline MSKS & $5.33 \pm 1.33 b$ & $32.00 \pm 2.31 \mathrm{~d}$ & $58.67 \pm 6.06 b$ \\
\hline KJ3R3 & $1.33 \pm 1.33 \mathrm{ab}$ & $8.00 \pm 2.31 b c$ & $18.67 \pm 2.18 \mathrm{a}$ \\
\hline LK & $1.33 \pm 1.33 \mathrm{ab}$ & $4.00 \pm 0.00 \mathrm{ab}$ & $10.67 \pm 2.88 \mathrm{a}$ \\
\hline TPP & $0.00 \pm 0.00 \mathrm{a}$ & $5.33 \pm 1.33 \mathrm{ab}$ & $13.33 \pm 1.09 \mathrm{a}$ \\
\hline CI4 & $1.33 \pm 1.33 \mathrm{ab}$ & $4.00 \pm 4.00 \mathrm{ab}$ & $6.67 \pm 2.18 \mathrm{a}$ \\
\hline Control & $0.00 \pm 0.00 \mathrm{a}$ & $0.00 \pm 0.00 \mathrm{a}$ & $4.00 \pm 0.00 \mathrm{a}$ \\
\hline$F$ value & 7.19 & 22.74 & 26.84 \\
\hline F Tab & 2.30 & 2.30 & 2.30 \\
\hline P-Value & 0.00 & 0.00 & 0.00 \\
\hline Tukeys HSD tests & 12.40 & 14.08 & 19.80 \\
\hline
\end{tabular}

Note: significantly different; values within a column (the data of each isolate) followed by the same letters were not significantly different at $\mathrm{P}<0.05$ according to Tukey's HSD test. Original data were transformed using Arcsin transformation prior to statistical analysis

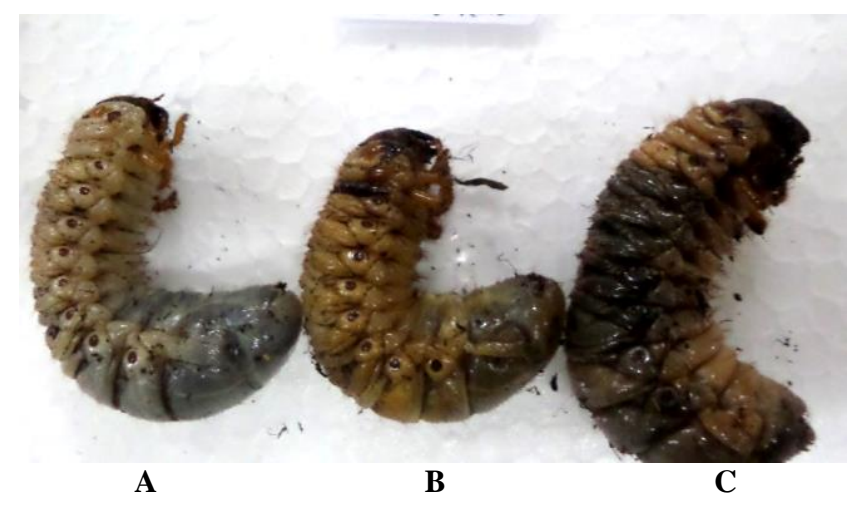

Figure 4. Symptoms of death of Oryctes rhinoceros. A. Healthy larvae, B. Larvae with symptoms of Bt infection, C. dead larvae

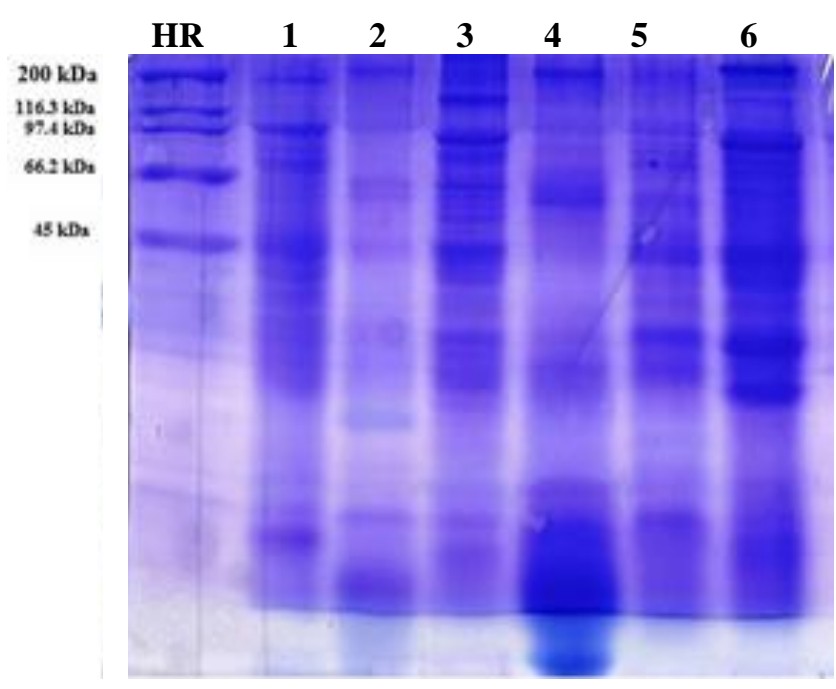

Figure 5. Molecular weight of B. thuringiensis isolates as a result of isolation from the soil South Sumatra. Note: 1. SMR, 2. MSP, 3. KJ3R5, 4. KJ3P1,5, SASU, 6. MSKS

\section{Discussion}

Sampling sites were varied in microclimate and altitude. The city of Pagar Alam located at an altitude of $780 \mathrm{~m}$ is a plateau area (Table 1). From overall isolation, soil samples taken from the city of Pagar Alam were found to be the highest of B. thuringiensis isolates (72\%). In observations, it may approve that sampling in natural habitats and not widely applied to chemicals (pesticides and fertilizers). Fernandes and López-Pazos (2011) reported B. thuringiensis composition seems to be influenced by several factors including soil humidity, organic matter, temperature, structure and $\mathrm{pH}$, macro/micro-nutrients, richness, and local insect distribution.

Some B. thuringiensis isolates were toxic to $S$. litoralis larva and some were toxic to $O$. rhinoceros larvae (Table 2 ). It has been expected that $B$. thuringiensis isolates which actively control $S$. litoralis larvae contained a special protein. Likewise, isolates that kill $O$. rhinoceros larvae contained special genes and proteins. This was consistent with the opinion of Fernandes and López-Pazos (2011) who reported biodiversity of active proteins against insects. Proteins were composed of several polypeptides bound together and the polypeptides had molecular masses ranging from $27 \mathrm{kDa}$ to $140 \mathrm{kDa}$. B. thuringiensis active against $S$. litoralis larvae (Lepidopteran order) may be inactive against $O$. rhinoceros larvae (Coleopteran order) (van Frankenhuyzen 2009).

The growth of various isolates in NB media and Biuorine media enriched with 5\% molasses showed similar tendency. Spore production at 24-hour observations was seen to be lowest followed by 48-hour and 72-hour observations. The increasing number of spores may be caused by the process of sporulation in which the less the content of materials needed to grow, the bacterial cells were forced to form spores and proteins. This occurrence was also reported by Valicente et al. (2010), Marzban (2012) and Sarrafzadeh (2012) which stated a certain C/N ratio was required to produce a number of spores and proteins toxic to insects. In addition, it was suspected that utilization of biourine enriched with 5\% molasses can be substitute for expensive chemical manufacturing materials such as NB. The use of agricultural and livestock waste materials (in this case biourine cattle) and molasses (sugar factory waste) was very important. Aside from utilizing abundant waste, this method was easily imitated and used by farmers. Some researchers use agricultural or livestock waste materials and apparently showed high toxicity to target insects (Prabakaran et al. 2008; Valicente et al. 2010; Salazar-Magallon et al. 2015)

Mortality of insects was caused by the presence of spores and bacterial proteins ingested in the midgut. Death of an insect usually took time. The process of mortality started from changing protein into a toxin (in the midgut) and then spreads throughout the hemolymph. Insects usually experienced septicemia and eventually die (Bravo et al. 2015c; Soberon et al. 2018). Until recently, it was known that few isolates were able to actively kill $O$. rhinoceros larvae. With a hard body texture and large size, it was necessary to isolate $B$. thuringiensis which contained 
a special protein with a molecular weight of around 14-133 $\mathrm{kDa}$ (Jouzani et al. 2017). In addition, it is also necessary to match the midgut conditions with alkaline $\mathrm{pH}$ in order to break down proteins into toxins (Soberon et al. 2018). According to Khaerani et al. (2012), the toxicity difference of $B$. thuringiensis local isolate might be caused by the difference of strain, size, and type of crystal protein produced.

Protein of $B$. thuringiensis infected larvae through midgut epithelial cells resulting in death of the host by septicemia and production of toxins. The body becomes soft as reported by Frederici et al. (2010). In some target insects, Cry proteins merely were sufficient to intoxicate larvae by destroying enough midgut epithelial cells. As a result, it allowed the alkaline midgut juices to flow into the hemolymph and raise the blood $\mathrm{pH}$ induced paralysis and cessation of feeding.

In relationship with mortality rate of $O$. rhinoceros where KJ3P1 and KJ3R5 isolates were $81.33 \%$ and $86 \%$ (Table 4), it was seen both isolates contained proteins that potent to kill $O$. rhinoceros larvae $(70-80 \mathrm{kDa})$. Therefore they caused high mortality against $O$. rhinoceros larvae. Interestingly, a single strain of $B$. thuringiensis may contain more than one crystal protein gene (Letowski et al. 2005; Pedro and Ibarra 2010). As reported by Fernandes and López-Pazos (2011) Coleopteran specificity Cry proteins had molecular weights Cry1Ia (81.2 kDa), Cry1Ba (139.6 kDa), Cry3 (72-75 kDa), Cry6Aa1 (54 kDa), Cry8 (130$133 \mathrm{kDa})$, Cry34 (14kDa) and Cry35 (44 kDa). Jouzani et al. (2017) also reported that cry gene cry3, cry7, cry8, cry14, cry18, cry 23 , cry 26 , cry 28 , cry34, cry35, cry366, cry366, cry37, cry38, cry43, and cry55 had effectiveness in killing Coleopteran insect.

In general, $B$. thuringiensis bacteria isolated and identified from soil of South Sumatra possessed a high potential in controlling $O$. rhinoceros even though mortality rate of the insect was not optimal yet. $B$. thuringiensis with molecular weight characteristics of 14$133 \mathrm{kDa}$ has the opportunity to control pests of the order Coleoptera because of the alleged suitability of acidity in the midgut larvae of $O$. rhinoceros. Application of agricultural and livestock waste as propagation media was one alternative in production of $B$. thuringiensis- based bioinsecticides that are cheap and safe for the environment.

\section{ACKNOWLEDGMENTS}

The data presented in this paper is part of the data from research results funded by the Directorate General of Higher Education, Ministry of Research and Higher Education through the Basic Research Grants Scheme in 2019.

\section{REFERENCES}

Ahmad MN, Kamarudin N, Ahmad SN, Arshad O, Masri MMM, Moslim R, Kushairi A. 2017. Efficacy of pheromone trapping and aerial spraying of Bacillus thuringiensis (Bt) for controlling bagworm,
Metisa plana Walker (Lepidoptera: Psychidae) in Yong Peng, Johor, Malaysia. J Oil Palm Res 29 (1): 55-65.

Bravo A, Diana L, de Castro M, Sanchez J. 2015a. Mechanism of action of Bacillus thuringiensis insecticidal toxins and their use in the control of insect pests. In: Alouf JE, Popoff MR (eds.) The Comprehensive Sourcebook of Bacterial Protein Toxins. Elsevier, Amsterdam.

Bravo A, Gómez I, Mendoza-Almanza G, Gaytan M. 2015b. Different models of the mode of action of 3d-Cry toxins from Bacillus thuringiensis. In: Alouf JE, Popoff MR (eds.) The Comprehensive Sourcebook of Bacterial Protein Toxins. Elsevier, Amsterdam.

Bravo A, Soberon M, Gill SS. 2015c. Bacillus thuringiensis: Mechanisms and use. In: Gilbert LI, Gill SS (eds.). Insect Control Biological and Synthetic Agent. Academic Press, Amsterdam.

Federici BA, Park HW, Bideshi DK. 2010. Overview of the basic biology of Bacillus thuringiensis with emphasis on genetic engineering of bacterial larvicides for mosquito control. Open Toxinol J 3: 154-171

Fernández JH, López-Pazos SA. 2011. Bacillus thuringiensis: Soil microbial insecticide, diversity and their relationship with the entomopathogenic activity In: Soil Microbes and Environmental Health. Chapter 3. ISBN 978-1-61209-647-6. Editor: Mohammad Miransari, pp. (C) 2011 Nova Science Publishers, Inc. 24 p.

He F. 2011. Laemmli-SDS-PAGE. Bio-101: e80. DOI: 10.21769/BioProtoc.80. June 05, 2011

Jouzani G.S, Valijanian E, Sharafi R. 2017. Bacillus thuringiensis: a successful insecticide with new environmental features and tidings. Appl Microbiol Biotechnol (2017) 101:2691-2711 DOI 10.1007/s00253-017-8175-y

Kamarudin N, Ahmad Ali SA; Mohd Masri MM; Ahmad MN; Che Manan CAH, Kamarudin N. 2017. Controlling Metisa plana Walker (Lepidoptera:psychidae) outbreak using Bacillus thuringiensis at an oilpalm plantation in Slim River Perak. Malaysia. J Oil Palm Res 29 (1): 47-54.

Khaeruni R, Purnamaningrum. 2012. The isolation of Bacillus thuringiensis Berl. from land and its pathogenicity to Crocidolomia binotalis Zell larvae on the Sawi Plant (Brassica juncea L.). J Agroteknos 2: 21-27.

Letowski J, Bravo A, Brousseau R, Masson L. 2005. Assessment of cry1 gene contents of $B$. thuringiensis strains by use of DNA microassays. Appl Environ Microbiol 71 (9):5391-5398

Marzban R. 2012. Investigation on the suitable isolate and medium for production of Bacillus thuringiensis. J. Biopest. 5 (2): 144-147.

Mizuki E, Ichimatsu T, Hwang S.-H, Park Y.S, Saitoh H, Higuchi K, Ohba M. 1999. Ubiquity of Bacillus thuringiensis on phylloplanes of arboreous and herbaceous plants in Japan. J Appl Microbiol 86: 979984.

Osman GEH, Already R, Assaeedi ASA, Organji SR, El-Ghareeb D, Abulreesh HH, Althubiani AS. 2015. Bioinsecticide B. thuringiensis a Comprehensive Review. Egypt J Biol Pest Contr 25 (1), 271-288.

Pedro AN, Ibarra JE. 2010. Detection of new cry genes of Bacillus thuringiensis by use of a novel PCR primer system. Appl Environ Microbiol 76: 6150-6155.

Prabakaran G, Hoti SL, Manonmani AM, Balaraman K. 2008. Coconut water as a cheap source for the production of endotoxin of Bacillus thuringiensis var. israelensis, a mosquito control agent. Acta Trop 105 (1): 35-38.

Pujiastuti Y, Astuti DT, Afriyani SR, Suparman S, Irsan C, Sembiring E R, Nugraha S, Mulawarman, Damiri N. 2018. Characterization of Bacillus thuringiensis Berl. indigenous from soil and its potency as biological agents of Spodoptera litura (Lepidoptera: Noctuidae). IOP Conf. Ser.: Earth Environ. Sci. 102: 01206. DOI: 10.1088/17551315/102/1/012064.

Purnawati R, Sunarti TC, Syamsu K, Rahayuningsih M. 2014. Characterization of novel Bacillus thuringiensis isolated from Attacus atlas and its growth kinetics in the cultivation media of tofu whey for bioinsecticide production. J Biol Agri Healthcare 4 (16): 33-40.

Rusmana I, Hadioetomo, R.S. 1994. Isolation of Bacillus thuringiensis Berl. from silkworm farms and their toxicity to the larvae of Crocodolomia binotalis Zell and Spodoptera litura F. Hayati 1 (1): 22-23.

Salazar-Magallon J.A, Hernandez-Velazquez VM, Alvear-Garcia A, Arenas-Sosa I, Peña-Chora G. 2015. Evaluation of industrial byproducts for the production of Bacillus thuringiensis strain GP139 and the pathogenicity when applied to Bemisia tabaci nymphs. Bull Insectol 68 (1): 103-109. 
Santi I.S, Sumaryo B. 2008. Effect of the color of pheromone towards number of trapped Oryctes rhinoceros in oil palm estate. Jurnal Perlindungan Tanaman Indonesia. 14 (2): 76-79. [Indonesian]

Sarrafzadeh MH. 2012. Nutritional Requirements of Bacillus thuringiensis during different phases of growth, sporulation and germination evaluated by Plackett-Burman method. Iran J Chem Chem Eng 31 (4): 131-136.

Soberón M, Monnerat R, Bravo A. 2018. Mode of action of cry toxins from Bacillus thuringiensis and resistance mechanisms. In: Gopalakrishnakone P, Stiles B, Alape-Girón, A, Dubreuil, J.D, Mandal, M. (eds.). Microbial Toxins. Springer Science+Business Media, Dordrecht.

Sudharto PS, Guritno P. 2003. Biological control of oil palm nettle caterpillars in Indonesia: review of research activities in Indonesia.
Proceedings of the PIPOC 2003 International Palm Oil Congress. Indonesian Oil Palm Research Institute (IOPRI), Medan.

Susanto A, Sudharto, Prasetyo AE. 2011. Information of insect pest Oryctes rhinoceros Linn. Indonesian Oil Palm Research Institute, Medan. [Indonesian]

Valicente FH, Tuelher EDS, Leite MIS, Freire FL, Vieira CM. 2010. Production of Bacillus thuringiensis biopesticide using commercial lab medium and agricultural by-products as nutrient sources. Revista Brasileira de Milho e Sorgo 9 (1): 1-11.

van Frankenhuyzen K. 2009. Insecticidal activity of Bacillus thuringiensis crystal proteins. J Invertebr Pathol 101 (1): 1-16.

Wiest SLF, Pilz Júnior HL, Fiuza LM. 2015. Thuringiensin: a toxin from Bacillus thuringiensis. Bt Research 6 (4): 1-12. 